\title{
Review of Peter J. Boettke's F. A. Hayek: Economics, Political Economy and Social Philosophy. London: Palgrave Macmillan, 2018, 323 pp.
}

\section{LACHEZAR GRUDEV \\ University of Freiburg}

Friedrich A. Hayek is often considered to have been an economist and a social philosopher who was a strong free-market proponent and who argued that markets are perfectly efficient in generating an optimal allocation of resources. In his recently published book, F. A. Hayek: Economics, Political Economy and Social Philosophy, Professor Peter J. Boettke argues that such claims represent a common misconception about Hayek's central ideas. Boettke's book aims to clarify these misconceptions because, he argues, they prevent us from understanding Hayek's arguments. For Boettke, these arguments are still relevant to contemporary discussions and can contribute a lot to our debates, particularly in the methodology of the social sciences and in technical economics.

This review will discuss those points in Boettke's book that we as economists lack in our model-based thinking, but that are, nevertheless, highly relevant to our efforts to grasp reality. The book is highly recommended for academics concerned with technical economics as it is an invitation to talk about thinkers, whose theories have either been misinterpreted or unjustly remained forgotten in the old books.

Boettke's book conveys the simple message that the history of economics matters since it provides valuable answers to highly topical questions, such as the role of the institutional framework on the economic process. Boettke argues that Hayek was involved in many debates during the 1930-1960 in economics and political economy which gave rise to a renewed focus on the institutional framework within which economic activity takes place. After this period Hayek explored the discovery and learning aspects of alternative institutional arrangements, which Boettke defines as epistemic institutionalism. Here, the fundamental question concerns the institutional prerequisites for learning and error correction among individuals in a society. By focusing on this, the book derives important implications for the methodology of 
the social sciences, for analytical economics, and for practical public policy.

\section{Hayek as a Technical Economist: The Coordination Problem}

Fundamental to understanding Hayek's epistemic institutionalism are the chapters "Hayek: An Overview of His Life and Work" and "The Anatomy of an Economic Crisis: Money, Prices, and Economic Order". Here, Boettke points out that Hayek was influenced by the earlier generations of the Austrian School, particularly Friedrich von Wieser and Ludwig von Mises. In his early period, Hayek incorporated Austrian concepts into his explanation of the exchange process and the structure of production. At the same time, Boettke delineates the main difference between Keynes and Hayek. For Hayek, macroeconomics obscures the economic problem which should be viewed as a coordination process of economic activity through time. Relative prices guide future exchange and production decisions, and thus agents' economic plans, because producers utilize the price system with the intention to "make rational economic calculation about alternative courses of action in commercial activity" (p. 42).

In his technical books on cyclical fluctuations, Hayek showed the fatal consequences that might result when relative prices fail to fulfill this information function. Based on Böhm-Bawerk's concept of a production period and on Mises's monetary theory, Hayek pointed out that if the money interest rate is manipulated and artificially lowered below the natural interest rate, then producers would concentrate their resources on ventures that had not been profitable before the change in the interest rate. This affects relative prices which, in turn, influences the decision-making of the producers and alters the production structure of the economy. The new production structure is not sustainable because commercial banks would at some point be compelled, first, to raise the interest rate due to liquidity reasons and, second, to curtail the credit provision for new ventures to the producers. Market participants would realize that they had been misinformed. The result would be a crisis and a depression that Hayek characterized as necessary adjustment processes to the pre-boom production structure of the economy.

\section{HAYEK AS A Political Economist: THE Institutional INFRASTRUCTURE}


During the following decades, Hayek refined his ideas on the coordination process in the economy. This is illustrated most convincingly in Boettke's chapter "Hayek on Market Theory and the Price System". This chapter focuses on how Hayek integrated the role of institutions regarding the acquisition and transmission of knowledge into his analysis of the coordination of the economic agents' plans. What is fundamental for Hayek is that knowledge is never given to any single mind, but that it is dispersed throughout society. This allows each member of a society to possess a small bit of an incomplete and subjective knowledge pertaining to a specific time and place. Boettke points out that for Hayek the price system represented a fundamental "mechanism for communicating information" about the relative scarcity of resources, and enabled individuals to act "as if they possessed more knowledge than a single mind could grasp without the use of the price system" (p. 86).

Boettke underlines that for Hayek knowledge incorporated in prices was not sufficient for the spontaneous coordination of economic plans. The subjective knowledge about objective facts, such as the alternative uses of one good or its different substitutes known to the acting agent, is acquired not only from the price system. Hayek considered the competitive market process to be the central institution for knowledge acquisition. The reason for this is that competition with its trial and error experimentation works as a discovery procedure. This procedure reveals facts, such as new ways of production, of which the individual has so far been unaware. Boettke claims that for Hayek competition is "an institutionally-contingent social process" (87) because, in order to work as a discovery procedure fostering innovations and experimentations, specific institutional prerequisites must be fulfilled: property rights, a functioning price system, a limited government, and the rule of law.

Boettke uses this discussion to clarify specific misconceptions in modern informational economics. This research program claims that Hayek treated knowledge of prices as the only relevant type of knowledge and that this knowledge is sufficient for attaining equilibrium. Boettke traces this claim to explicit sections in the papers of Grossman (1976), and Grossman and Stiglitz (1976, 1980), who argued that economic agents, who know the price system and act out of self-interest, can generate resource allocations in a given economy. But this economy should not be viewed as automatically stable "because 
prices are revealing so much information that incentives for the collection of information are removed. [...] It is not enough for traders to observe only prices" (Grossman 1976, 585) (105). Boettke shows that this stands in complete contrast to Hayek's statement that the price system is not sufficient for achieving equilibrium. Individuals have to possess additional knowledge in order to adapt their plans to the changing circumstances.

In the chapter "Hayek and Market Socialism", Boettke asserts that these arguments provide the basis for Hayek's response to the intellectual challenges facing the advocates of socialism, particularly Oskar Lange and Abba Lerner. They aimed at developing a "market socialism", in which a figure akin to the Walrasian auctioneer would emulate "the tâtonnement process under general competitive equilibrium" (p. 23). Here producer markets can be abolished because their vulnerability to cyclical fluctuations gives rise to depressions, and thus to unemployment and poverty. The prices for producer goods can be computed based on the marginal theory of value. A 'central planning board' can be established that replaces the unstable markets and that communicates to the managers of state-owned firms how to produce in an optimal manner.

Boettke asserts that Hayek treated such planning processes as impossible because price imputation is not a trivial procedure. Producers rely on many signals that guide them in deciding which methods to use for production. This requires market participants to be adaptable to changing circumstances; it requires an adaptability, which is based on subjective knowledge regarding specific methods of production. Price competition creates an incentive for entrepreneurs to acquire knowledge regarding the best and cheapest methods of production. Hence, the average cost curve is not a given fact for entrepreneurs, as the market socialists think, but a result of the complicated discovery procedure taking place within the market process. While price competition fosters an incentive to acquire knowledge about the best method of production, for Hayek, institutions enable entrepreneurs to acquire this knowledge pertaining to the specific context in which entrepreneurs evaluate their past decisions and make new decisions, with the final goal of coordinating their plans with those of the other market participants.

\section{Hayek as A Social Philosopher: The Liberal Order}


Let us conclude with the main message of the chapters "The Reconstruction of the Liberal Project" and "The Hayekian Legacy". These chapters point out why Hayek's intellectual legacy is topical today when populist movements from the left and the right with their nationalistic and anti-globalist rhetoric are challenging the foundations of free societies. These two chapters can be read as an appeal particularly to economists as social scientists. An appeal to put aside formalism and rational-choice models so as to understand Hayek's main message: that the problem of economics is the coordination of dispersed knowledge in society. Coordination requires institutions that enable people to learn what they want to learn, so that coordination of plans which are fundamental to prosperity and welfare can be promoted. This explains why institutions play an important epistemic role in encouraging peaceful cooperation among different individuals independently of their language, ethnicity, race, religion and geography. The theorists of liberalism have been clarifying how this institutional framework creates the conditions for such a peaceful coordination and increases the costs of discrimination based on religion, gender, and race. Boettke argues that a basic idea of liberalism has been the normative vision of the classical political economists since Adam Smith.

This book is highly recommended not only for Hayek experts and academics interested in Hayek's intellectual legacy, but also, and particularly, for economists engaged in technical economics. Boettke's book advances Hayek's epistemic institutionalism as an important constructive program, because it accentuates the relevance of institutions to the coordination of market participants, and thus to how institutions shape economic processes. By clarifying the common misconceptions about Hayek, Boettke's book invites us to reread Hayek, putting our ideological glasses aside. Boettke convincingly describes Hayek's story as that of an economist and a social philosopher who was also concerned with understanding the reality by seeking an answer to a very simple question: what enables us, fallible, but capable individuals, to coordinate our "affairs with one another and realize productive specialization and peaceful cooperation" (229), giving rise to the tremendous increases in wealth and prosperity observed in the last two centuries. Understanding Hayek's answer to this question and overcoming our prejudices about Hayek's theoretical approach will contribute to the progress of economic science. 


\section{REFERENCES}

Grossman, Sanford J. 1976. "On the Efficiency of Competitive Stock Markets Where Trades Have Diverse Information.” The Journal of Finance 31 (2): 573-585.

Grossman, Sanford J. and Joseph E. Stiglitz. 1976. "Information and Competitive Price Systems." The American Economic Review 66 (2): 246-253.

Grossman, Sanford J. and Joseph E. Stiglitz. 1980. "On the Impossibility of Informationally Efficient Markets." The American Economic Review 70 (3): 393408.

Lachezar Grudev is a $\mathrm{PhD}$ student in economics at the University of Freiburg, Germany. His research interests include history of economic thought, history of business cycle theories, economic methodology, constitutional economics and public choice. He is a member of History of Economics Society and Wilhelm-Röpke-Institute. He is also a Mercatus Center Adam Smith fellow during the 2018-2019 academic year.

Contact e-mail: <lachezar.grudev@vwl.uni-freiburg.de> 